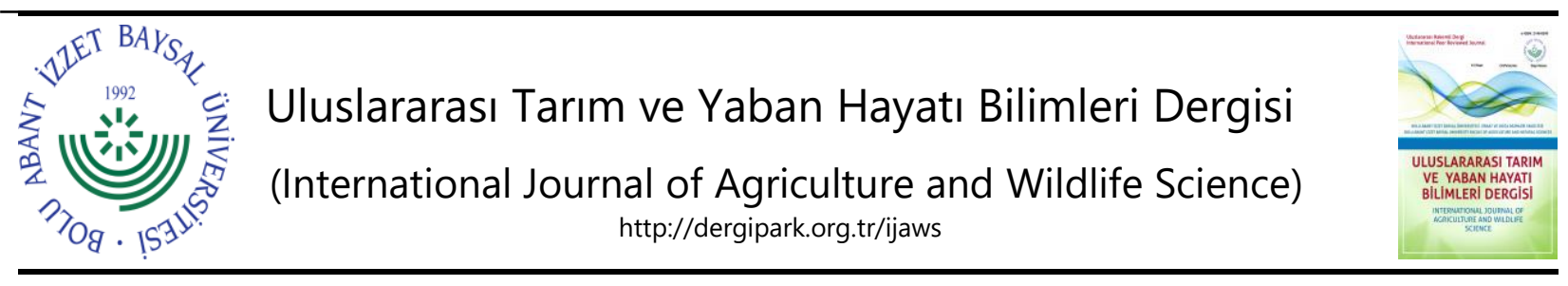

Araştırma Makalesi

\title{
Fındıkta Bitki Besin Elementleri ile Verim ve Meyve Özellikleri Arasındaki iliş̧ki
}

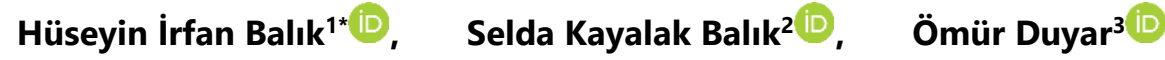 \\ 1Sakarya Uygulamalı Bilimler Üniversitesi, Ziraat Fakültesi, Bahçe Bitkileri Bölümü, Sakarya \\ ${ }^{2}$ Tarım ve Orman İ Müdürlüğü, Sakarya \\ ${ }^{3}$ Tarım ve Orman İl Müdürlüğü, Ordu
}

Geliş tarihi (Received): 03.03.2021 Kabul tarihi (Accepted): 04.05.2021

\begin{abstract}
Anahtar kelimeler:
Corylus avellana L., bitki besleme, meyve kalitesi, korelasyon analizi, regresyon analizi
\end{abstract}

*Sorumlu yazar

h.irfanbalik@gmail.com
Özet. Bu araştırmada, fındık bahçelerinin bitki besin elementi içerikleri ile verim ve kalite özellikleri arasındaki ilişki belirlenmiştir. Tombul fındık çeşidinde yürütülen çalışmada tespit edilen bitkilerin yaprak ve meyve örnekleri incelenmiştir. İncelenen bitkilerde verim 274-1523 g bitki ${ }^{-1}$, meyve ağırlığı 1.67$2.19 \mathrm{~g}$, iç ağırlığı 0.90-1.19g, iç oranı \%34.9-54.2, sağlam iç oranı \%67.7-90.3, kabuk kalınlığı 0.89$1.10 \mathrm{~mm}$, çotanaktaki meyve sayısı 2.15-4.38 adet, tam beyazlama oranı \%63.5-98.9, çıtlak meyve oranı \%0.3-15.3 ve göbek boşluğu $1.70-2.86 \mathrm{~mm}$ arasında belirlenmiştir. Korelasyon analizi sonucunda, verim ile meyve ağırlığı $\left(r=0.390^{* *}\right)$, kabuk kalınlığı $\left(r=0.382^{* *}\right)$ ve yapraklardaki bor (B) içeriği $\left(r=0.429^{* *}\right)$ arasında ilişkilerin önemli olduğu belirlenmiştir. Meyve ağırlığı ile iç ağırlığı $\left(r=0.889^{* *}\right)$, sağlam iç oranı $\left(r=0.303^{*}\right)$, kabuk kalınlığı $\left(r=0.564^{* *}\right)$ ve göbek boşluğu $\left(r=0.473^{* *}\right)$ arasındaki ilişkinin önemli olduğu saptanmıştır. İç ağırlığı ile göbek boşluğu $\left(r=0.405^{* *}\right)$ ve Mn içeriği $\left(r=-0.349^{*}\right)$; iç oranı ile sağlam iç oranı $\left(r=0.432^{* *}\right)$; sağlam iç oranı ile kabuk kalınlığı $\left(r=0.319^{*}\right)$; göbek boşluğu ile K içeriği $\left(r=0.342^{*}\right)$; $K$ içeriği ile $B$ içeriği $\left(r=0.300^{*}\right)$ arasındaki ilişkinin önemli olduğu tespit edilmiştir. Regresyon analizi sonucuna göre verim üzerine B içeriği ile birlikte, meyve ağırlığının pozitif etkisi söz konusu iken, iç ağırlığının negatif etkisi belirlenmiştir. Verime etki eden özellikler dikkate alınarak oluşturulan kümeleme analizi sonucunda bitkilerin 3 gruba ayrıldığı tespit edilmiştir. 1. ve 2. grupta verim, sağlam iç oranı, beyazlama oranı düşük olan bitkiler yer alırken; 3. gruptaki bitkilerde verimin oldukça yüksek olduğu, meyve kalite özelliklerinin 1. ve 2. gruptaki bitkilere nazaran daha iyi ve besin elementlerinden özellikle B bakımından oldukça zengin olduğu tespit edilmiştir.

\section{Relationship Between Plant Nutrient Elements and Yield and Nut Characteristics in Hazelnut}

Keywords:
Corylus avellana L., plant
nutrition, nut quality,
correlation analysis,
regression analysis

Keywords:

Corylus avellana L., plant correlation analysis, regression analysis

Abstract. In this study, the relationship between nutritional content and yield and quality of Tombul hazelnut orchards were determined. As a result of analysis, yield $274-1523 \mathrm{~g} \mathrm{plant}^{-1}$, nut weight 1.67 2.19g, kernel weight $0.90-1.19 \mathrm{~g}$, kernel ratio $34.9-54.2 \%$, good kernel $67.7-90.3 \%$, shell thickness 0.89 $1.10 \mathrm{~mm}$, number of nuts in cluster 2.15-4.38, pellicle removal was determined between $63.5-98.9 \%$, cracked nut between $0.3-15.3 \%$ and kernel cavity between $1.70-2.86 \mathrm{~mm}$. As a result of the correlation analysis, it was determined that the relationship between yield and nut weight $\left(r=0.390^{\star *}\right)$, shell thickness $\left(r=0.382^{\star \star}\right)$ and $B\left(r=0.429^{\star \star}\right)$ were found to be significant. The relationship between nut weight and kernel weight $\left(r=0.889^{* *}\right)$, kernel ratio $(r=0.303 *)$, shell thickness $\left(r=0.564^{\star *}\right)$ and kernel cavity $\left(r=0.473^{\star \star}\right)$ were found to be significant. Kernel cavity $\left(r=0.405^{\star \star}\right)$ and $\mathrm{Mn}(r=-0.349$ *) with kernel weight; kernel ratio with good kernel $\left(r=0.432^{\star \star}\right)$; shell thickness with kernel ratio $\left(r=0.319^{\star}\right)$; $K$ with kernel cavity $\left(r=0.342^{*}\right)$; relationship between $\mathrm{K}$ and $\mathrm{B}\left(\mathrm{r}=0.300^{*}\right)$ were found to be significant. According to the regression analysis, the positive effect of the nut weight together with the $B$ on the yield was determined, while the negative effect of the kernel weight was determined. As a result of cluster analysis, it was determined that the plants were divided into 3 groups. In groups 1 and 2, there are plants with yield, good kernel; In group 3, that the yield is very high in the plants, the nut quality is better than the $1^{\text {st }}$ and $2^{\text {nd }}$ groups, and they are quite rich in nutrients, especially boron. 


\section{GiRiş}

Fındık Fagales takımı, Betulaceae familyası, Coryloidea alt familyasının Corylus cinsi içerisinde yer almaktadır (Germain, 1990; Erdoğan ve Mehlenbacher, 2000). Türkiye, Corylus cinsi içerisinde yer alan önemli fındık türlerinden C. avellana ve C. colurna'ya ev sahipliği yapmaktadır. Kültür fındıklarının içerisinde yer aldığı $C$. avellana'nın ilk kültüre alındığı yer Anadolu'dur. Türkiye yaklaşık 734.000 hektar üretim alanı ile dünya fındık üretim alanının \%73'nü oluşturmakta, yıllık ortalama 572.000 ton üretim ile dünya fındık üretiminin \%65'ni gerçekleştirmektedir. Türkiye'nin dışında önemli fındık üreticisi ülkeler İtalya, Azerbaycan, ABD ve İran'dır (FAO, 2021). Türkiye'de üretilen fındığın \%80-85'i ihraç edilmekte olup, bu ihracattan ortalama 1.9 milyar dolar gelir elde edilmektedir (Anonim, 2021a). Ülkemizin fındık ihracatından elde ettiği gelir toplam tarımsal ürün ihracatının \%10'una denk gelmektedir. Karadeniz çiftçisinin ana geçim kaynağı olması, doğrudan ve dolaylı olarak yaklaşık sekiz milyon vatandaşımızın geçim kaynağını oluşturması ve dışarıdan hiçbir girdi kullanımı olmadan ülkemize büyük miktarda döviz kazandırması nedeniyle fındık, önemli bir tarımsal üründür.

Meyve türlerinin büyümesi ve gelişmesinin yanı sıra, verim ve kalite özelliklerinin ortaya çıkmasında genetik yapı, tozlayıcı çeşit, iklim ve toprak özellikleri, budama, gübreleme, sulama, bitki besleme ve hastalık-zararlılarla mücadele gibi kültürel uygulamalar etkili olmaktadır. Bu faktörler, kontrol edilebilen ve kontrol edilemeyen özellikte olup; bitki besleme, üreticiler tarafından kontrol edilebilen faktörler içerisinde yer almaktadır (Herrera, 2001; Balık ve Beyhan, 2019). Fındık kökleri her yıl topraktan devamlı olarak besin maddesi almaktadır. Zamanla toprakta besin maddelerinin tükenmesi ile gelişim bozuklukları ve üründe azalmalar meydana gelir. Toprakta noksan olan besin maddelerinin tekrar toprağa gübre ile verilmesindeki başarı, toprakta hangi besin elementinin noksan olduğunun belirlenmesi ile mümkündür. Fındığın normal bir gelişme göstermesi ve istenilen verim seviyelerine ulaşması için intiyacı olan besin maddelerinin toprak ve yaprak analizleri ile belirlenmesi gerekmektedir. Fındığın gelişebilmesi için ihtiyacı olan besin maddeleri sadece azot, fosfor ve potasyum olmayıp genel fonksiyonları ve yaptıkları işlem bakımından bunlar kadar önemli olan $\mathrm{S}, \mathrm{Ca}, \mathrm{Mg}, \mathrm{Fe}, \mathrm{Mn}, \mathrm{Zn}, \mathrm{Cu}, \mathrm{B}$ gibi besin elementleri de bulunmaktadır. Bu besin maddeleri yaprak analizleri ile belirlenmektedir (Horuz ve Korkmaz, 2011). Fındıkta yaprak örnekleri hasattan 10-15 gün önce genellikle temmuz ayının ikinci yarısında alınır. Yaprak örnekleri, belirlenen ocaklarda ana dallar üzerinde gelişme gösteren 1 yıllık sürgünlerin 3. ve 4. yapraklarından alınmalıdır (Anonim, 2021b). Coşkun (2010), Giresun'daki fındık bahçelerinde incelenen mikro elementlerden Mn, $\mathrm{Fe}$ ve $\mathrm{Zn}$ içeriğinin yeterli seviyede, Cu ve B içeriğinin düşük seviyede olduğunu tespit etmiştir.

Makro ve mikro elementlerin fındıkta büyüme, meyve tutumu ve kalitesi üzerine etkileri hakkında araştırmalar söz konusudur. Özenç ve ark. (2014), fındıkta azot, fosfor ve potasyumlu gübrelerin biyokimyasal içerik ve mineral madde düzeyini önemli düzeyde etkilediğini, $200-400 \mathrm{~kg} \mathrm{ha}^{-1}$ azot, $120-160 \mathrm{~kg} \mathrm{ha}^{-1}$ fosfor ve $400-600 \mathrm{~kg} \mathrm{ha}^{-1}$ potasyumun bu özellikler açısından en yüksek etkiyi gösterdiğini belirlemiştir. Tombul fındık çeşidinde yüksek verim elde edebilmek için kasım ve şubat aylarında dal iz düşümüne $6 \mathrm{~g} \mathrm{ocak}^{-1}$ ve mayıs, eylül, çiçeklenmeden 20 gün önce olmak üzere $300 \mathrm{mg} \mathrm{It}^{-1}$ dozunda yapraktan bor uygulamasının faydalı olacağı vurgulanmıştır (Anonim, 2015). Nicolosi ve ark. (2009), fındıkta azotlu gübrelerin sürgün uzunluğu, verim, meyve boyutları ve iç oranını arttırdığını, boş meyve oranını ise azalttığını belirlemişlerdir. Borges ve ark. (2001), fındık yetiştiriciliğinde bor uygulamasının meyve tutumu, meyve büyüme ve gelişmesi ile meyve kalitesini olumlu etkilediğini tespit etmişlerdir. Pannico, (2014), Mortarella fındık çeşidinde bor, demir ve çinko uygulamasının vejetatif gelişmeye pozitif yönde katkı sağladığını; verime etkisinin ise olmadığını saptamış; yağ, protein, karbonhidrat ve yağ asidi kompozisyonuna etkisini önemli bulmuştur. Roversi and Ughini (2005), fındıkların mineral madde alımı ve kullanımının diğer meyve ağaçlarından daha az olduğunu vurgularken; düşük sıcaklık, yağmur veya kuraklık gibi çevresel koşullarının difüzyonu azalttığını ve bitkideki transpirasyonel akışı sınırlandırdığını ve bu nedenle, bazı besin elementlerinin topraktaki yeterli görünse bile bitki tarafından alınımında sorunlar oluşturabildiğini ifade etmişlerdir.

Fındık bahçelerinin besin elementi durumunu ortaya koyan araştırmalar bulunmakla birlikte, Tombul fındık çeşidinde bitki besin elementi içerikleri ile verim ve kalite arasındaki ilişkinin belirlendiği bir araştırma literatürde bulunmamaktadır. Bu araştırma, Tombul fındık bahçelerinin beslenme durumlarını ve bu bahçelerdeki bitkilerin besin elementi içerikleri ile verim ve kalite özellikleri arasındaki ilişkiyi belirlemek amacıyla yürütülmüştür. 


\section{MATERYAL VE METOT}

\section{Bitkisel Materyal}

Meyve ve yaprak örnekleri Giresun ve Trabzon illerindeki Tombul fındık bahçelerinden temin edilmiştir (Çizelge 1). 2010 yılı temmuz ayında yaprak örnekleri alınarak N, P, K, B, Cu, Fe, Mn ve $\mathrm{Zn}$ düzeyleri belirlenmiştir. Yaprak örneklerinin alındığı bitkilerde zurufların sararıp, kızarıp kahverengileşmeye başlaması, fındığın sert kabuğunun $3 / 4$ oranında kızarması ve nem oranının \%30'un altına düşmesi ile birlikte hasat yapılmıştır. Fındıklar zurufundan elle ayıklanmış ve beton zeminde güneş ışığında nem seviyesi \%6'nın altına düşene kadar kurutulmuş ve ardından pomolojik özellikleri belirlenmiştir. Araştırmada kullanılan Tombul fındık çeşidi, yaygın olarak Giresun'da yetiştirilmektedir. Yüksek yağ ve beyazlama oranı ile çerezlik ve sanayilik değeri ile öne çıkan bu çeşit hâlihazırda mevcut çeşitler öne çıkmaktadır. Meyve büyüklüğü $16.59 \mathrm{~mm}$, iç büyüklüğü $12.56 \mathrm{~mm}$, meyve ağırlığı $1.78 \mathrm{~g}$, iç ağırlığı $0.97 \mathrm{~g}$, kabuk kalınlığı $0.90 \mathrm{~mm}$, göbek boşluğu $1.51 \mathrm{~mm}$, iç oranı \%54.4, boş meyve oranı \%2, buruşuk iç oranı \%3, abortif iç oranı $\% 2$, çift iç oranı \%0.5, çıtlak meyve oranı $\% 1$, beyazlama oranı $\% 94.2$, protein oranı \%17.07, yağ oranı \%59.8 ve lifsizdir (Balık ve ark., 2016).

Çizelge 1. Deneme bahçelerine ait bilgiler.

Table 1. Information of trial orchards.

\begin{tabular}{|c|c|c|c|c|c|c|c|}
\hline No & il & İlçe & Köy/mevki & No & il & îlçe & Köy/mevki \\
\hline 1 & Giresun & Merkez & Çalışköy & 28 & Giresun & Görele & İnanca \\
\hline 2 & Giresun & Merkez & Kayadibi & 29 & Giresun & Görele & Dedeli \\
\hline 3 & Giresun & Merkez & Organize San. & 30 & Giresun & Görele & Dedeli \\
\hline 4 & Giresun & Merkez & Çaykara & 31 & Giresun & Görele & İsmailbeyli \\
\hline 5 & Giresun & Merkez & Çaykara & 32 & Giresun & Görele & Umutlu \\
\hline 6 & Giresun & Merkez & Çaykara & 33 & Giresun & Dereli & Çalca \\
\hline 7 & Giresun & Merkez & Çaykara & 34 & Giresun & Dereli & Sütlüce \\
\hline 8 & Giresun & Merkez & Çavuşoğlu & 35 & Giresun & Piraziz & Gökçeali \\
\hline 9 & Giresun & Merkez & Ülper & 36 & Giresun & Piraziz & Alidede \\
\hline 10 & Giresun & Merkez & Gürköy & 37 & Giresun & Piraziz & Esentepe \\
\hline 11 & Giresun & Merkez & Homurlu & 38 & Giresun & Piraziz & Yazıköy \\
\hline 12 & Giresun & Merkez & Homurlu & 39 & Giresun & Piraziz & Narlık \\
\hline 13 & Giresun & Merkez & Gürköy & 40 & Giresun & Keşap & Armelit \\
\hline 14 & Giresun & Merkez & Yağmurca & 41 & Trabzon & Beşikdüzü & Çeşmeönü \\
\hline 15 & Giresun & Merkez & Akçalı & 42 & Trabzon & Beşikdüzü & Kutluca \\
\hline 16 & Giresun & Keşap & Güneyköy & 43 & Trabzon & Beşikdüzü & Kutluca \\
\hline 17 & Giresun & Keşap & Kayabaşı & 44 & Trabzon & Beşikdüzü & Beşikdüzü \\
\hline 18 & Giresun & Espiye & Cibril & 45 & Trabzon & Beşikdüzü & Beşikdüzü \\
\hline 19 & Giresun & Espiye & Dikence & 46 & Trabzon & Çarşıbaşı & Kavaklı \\
\hline 20 & Giresun & Espiye & Gebelli & 47 & Trabzon & Çarşıbaşı & Kavaklı \\
\hline 21 & Giresun & Espiye & Gebelli & 48 & Trabzon & Çarşıbaşı & Zeytinlik Mah. \\
\hline 22 & Giresun & Eynesil & Ören & 49 & Trabzon & Vakfıkebir & Çamlık \\
\hline 23 & Giresun & Eynesil & Ören & 50 & Trabzon & Vakfıkebir & Çamlık \\
\hline 24 & Giresun & Eynesil & Yarımca & 51 & Trabzon & Vakfıkebir & Kemaliye \\
\hline 25 & Giresun & Görele & Çavuşlu/Yeniköy & 52 & Trabzon & Vakfıkebir & Büyükliman \\
\hline 26 & Giresun & Görele & Türkeli & 53 & Giresun & Merkez & Fındık A.E. \\
\hline 27 & Giresun & Görele & Ünlüce & & & & \\
\hline
\end{tabular}

\section{Metot}

\section{Pomolojik Özelliklerin Belirlenmesi}

Verim (V): Bitkideki meyvelerin tamamı hasat edilerek belirlenmiş ve $\mathrm{g} / \mathrm{bitki}$ olarak ifade edilmiştir.

Meyve ağırlığ (MA) (g): Incelemeye alınan örnekler doğal şartlarda kurutulduktan sonra her bir bitkiden tesadüfen seçilen 30 meyve $0.01 \mathrm{~g}$ 'a duyarlı hassas terazide tek tek tartılarak belirlenmiştir.

iç ağırlığı (IA) (g): Ağırlığı tespit edilen 30 adet meyvenin içi çıkarılarak 0.01g'a duyarlı hassas terazide tek tek tartılarak belirlenmiştir.

İç oranı (iO) (\%): Toplam iç ağırlığının toplam meyve ağırlığına oranlanması ile belirlenmiştir. Toplam 100 meyve kullanılarak hesaplanmıştır.

Sağlam iç oranı (SiO) (\%): Kabuğu iyice doldurmuş, buruşuk ve abortif olmayan içlerin tüm iç sayısına oranlanması ile belirlenmiştir.

Kabuk kalınlığı $(K K)(\mathrm{mm})$ : Tesadüfen seçilmiş olan 30 meyvede, meyvelerin tabla kısmı ile uç kısmının tam ortasındaki kabuk kalınlığı 0.01 mm'ye duyarlı dijital kumpas yardımıyla ölçülmüştür. 
Çotanaktaki meyve sayısı (ÇMS): Hasat edilen çotanaklardan rastgele seçilen 100 tanesindeki gelişimini tamamlamış meyveler sayılarak ortalaması alınmıştır.

Beyazlaşma oranı $(B O)$ (\%): Her bitkiden elde edilen 50 adet iç alüminyum kaplara konulmuş ve etüvde $175^{\circ} \mathrm{C}^{\prime}$ de $15 \mathrm{dk}$ bekletilerek elde ovalanarak tam beyazlaşma oranları belirlenmiştir.

Çıtlak meyve oranı (ÇMO) (\%): Sütur çizgisinin meyvenin uç kısmında birleştiği noktada açıklık varsa bu meyveler 'çıtlak meyve' olarak kabul edilmiştir.

Göbek boşluğu (GB) (mm): İç fındık kotiledon birleşme çizgisine dik olacak şekilde tam ortadan ikiye bölünmüş ve açığa çıkan göbek boşluğu uç ile dip arasındaki eksene dik olacak şekilde en geniş kısımdan $0.01 \mathrm{~mm}$ 'ye duyarlı dijital kumpasla ölçülmüştür.

\section{Yapraktaki Besin Elementi Düzeylerinin Belirlenmesi}

Yaprak örnekleri $65^{\circ} \mathrm{C}^{\prime}$ de etüvde kurutulup, bitki değirmenlerinde öğütülerek homojen hale getirilmiştir (Kacar ve İnal, 2008). Örneklerde toplam azot Kjeldal metodu ile belirlenmiştir (Keeney, 1982). Diğer besin elementlerinin analizi mikrodalga yaş yakma metodunda konsantre nitrik asit $\left(\mathrm{NO}_{3}\right)$ ve \%30'luk hidrojen peroksit $\left(\mathrm{H}_{2} \mathrm{O}_{2}\right)$ de örneklerin yakılması ile yapılmış ve okumalar Perkin Elmer Optical Emission Spectrometer Optima 2100 DV'de gerçekleştirilmiştir (Kacar ve İnal, 2008).

\section{Deneme Deseni ve istatistiksel Analizler}

Çalışma, tesadüf blokları deneme desenine göre 3 tekerrürlü olarak yürütülmüştür. Ele alınan özellikler arasındaki ikili ilişkilere ait korelasyon, regresyon ve kümeleme analizleri SPSS 16 programında yapılmıştır.

\section{BULGULAR VE TARTIŞMA}

\section{Verim ve Meyve Özellikleri}

Araştırmada Giresun 'da 41, Trabzon'da ise 12 Tombul fındık bahçesinden toplam 53 bahçede tespit edilen bitkilerde meyvelerin tamamı hasat edilerek verimleri belirlenmiş, meyvelerin pomolojik analizleri de yapılmıştır. Çalışma kapsamında değerlendirilen bitkilerin verimi $274-1523 \mathrm{~g} \mathrm{bitki}^{-1}$, meyve ağırlığı 1.67-2.19 g, iç ağırlığı 0.90$1.19 \mathrm{~g}$, iç oranı \%34.9-54.2, sağlam iç oranı \%67.7-90.3, kabuk kalınlığı 0.89-1.10 mm, çotanaktaki meyve sayısı 2.15-4.38 adet, tam beyazlama oranı \%63.5-98.9, çıtlak meyve oranı \%0.3-15.3 ve göbek boşluğu 1.70-2.86 mm arasında tespit edilmiştir (Çizelge 2). Verimdeki farklılıkların arazi yapısı, iklim koşulları ve kültürel uygulamalardaki farklııklardan kaynaklandığı değerlendirilmektedir. Nitekim Özkutlu ve ark. (2016) fındıkta verim düşüklüğünün sebeplerini dikim, budama, gübreleme, ilaçlama ve toprak işlemede yapılan hatalı uygulamaların yanı sıra toprakların az kireçli, eğimli, sığ, taşlı ve kayalı, su tutma kapasitesi yetersiz, aşırı killi, makro ve mikro besin elementi noksanlıkları, organik madde düzeylerinin yer yer düşük düzeyde olması olarak sıralamıştır. Bostan (2019) tarafından azot, fosfor ve magnezyum eksikliklerinin boş meyve oluşumuna etkisinin olmadığı; iyi bir potasyum beslenmesinin boş fındık sayısını azalttığı (Germain, 1994); 'Palaz' fındık çeşidinde farklı azot dozlarının sağlam iç oranı ve boş iç oranı üzerine etkisinin istatistik olarak önemli olmadığı (Beyhan ve ark., 1998); 'Tombul' çeşidinde yapraktan borik asit ve topraktan boraks uygulamalarının boş meyve oluşumunu azaltmada etkili olduğu (Okay ve ark., 1987) rapor edilmiştir. Balık ve ark. (2016), Tombul fındık çeşidinde meyve ağırlığını $1.78 \mathrm{~g}$, iç ağırlığını $0.97 \mathrm{~g}$, iç oranını \%54.4, kabuk kalınlığını $0.90 \mathrm{~mm}$, beyazlama oranını \%94.2, çıtlak meyve oranını \%1, göbek boşluğunu $1.51 \mathrm{~mm}$ olarak belirlemişlerdir.

Çizelge 2. Verim ve pomolojik özellikler.

Table 2. Yield and pomological characteristics.

\begin{tabular}{|c|c|c|c|c|c|c|c|c|c|c|}
\hline No & $\begin{array}{l}\text { V } \\
\left(\text { g bitki }{ }^{-1}\right)\end{array}$ & $\begin{array}{l}\text { MA } \\
(g)\end{array}$ & $\begin{array}{l}\text { iA } \\
(g)\end{array}$ & $\begin{array}{l}\text { io } \\
\text { (\%) }\end{array}$ & $\begin{array}{l}\text { sio } \\
(\%)\end{array}$ & $\begin{array}{l}\text { KK } \\
(\mathrm{mm})\end{array}$ & ÇMS & $\begin{array}{l}\text { BO } \\
(\%)\end{array}$ & $\begin{array}{l}\text { ÇMO } \\
\text { (\%) }\end{array}$ & $\begin{array}{l}\text { GB } \\
(\mathrm{mm})\end{array}$ \\
\hline 1 & 607 & 2.12 & 1.11 & 51.11 & 86.77 & 0.99 & 3.34 & 92.13 & 1.23 & 2.62 \\
\hline 2 & 399 & 2.13 & 1.09 & 49.73 & 86.10 & 1.06 & 3.18 & 94.37 & 1.19 & 2.50 \\
\hline 3 & 832 & 2.00 & 1.05 & 50.45 & 85.00 & 1.01 & 3.33 & 80.70 & 3.33 & 1.94 \\
\hline 4 & 586 & 1.84 & 0.96 & 49.07 & 75.67 & 0.95 & 3.06 & 92.73 & 1.67 & 1.96 \\
\hline 5 & 1453 & 1.94 & 1.04 & 52.44 & 88.00 & 0.96 & 3.10 & 89.77 & 3.33 & 1.95 \\
\hline 6 & 772 & 1.94 & 1.05 & 51.17 & 83.33 & 0.93 & 3.32 & 93.67 & 3.00 & 1.78 \\
\hline 7 & 419 & 1.86 & 1.01 & 52.94 & 83.53 & 0.91 & 2.82 & 98.90 & 3.11 & 2.47 \\
\hline 8 & 1159 & 1.93 & 1.06 & 53.58 & 82.67 & 0.91 & 3.35 & 91.60 & 7.00 & 1.99 \\
\hline 9 & 646 & 2.06 & 1.12 & 53.49 & 88.33 & 0.96 & 3.58 & 89.13 & 5.00 & 2.14 \\
\hline 10 & 941 & 2.01 & 1.05 & 50.73 & 80.67 & 0.97 & 2.83 & 85.13 & 3.33 & 2.35 \\
\hline 11 & 476 & 1.93 & 1.06 & 54.07 & 88.67 & 0.92 & 2.71 & 94.47 & 3.67 & 2.13 \\
\hline
\end{tabular}




\begin{tabular}{|c|c|c|c|c|c|c|c|c|c|c|}
\hline No & $\begin{array}{l}\text { V } \\
\left(g_{\text {bitki }}{ }^{-1}\right)\end{array}$ & $\begin{array}{l}\text { MA } \\
\text { (g) }\end{array}$ & $\begin{array}{l}\text { IA } \\
\text { (g) }\end{array}$ & $\begin{array}{l}\text { io } \\
\text { (\%) }\end{array}$ & $\begin{array}{l}\text { sio } \\
\text { (\%) }\end{array}$ & $\begin{array}{l}\mathrm{KK} \\
(\mathrm{mm})\end{array}$ & ÇMS & $\begin{array}{l}\text { BO } \\
\text { (\%) }\end{array}$ & $\begin{array}{l}\text { ÇMO } \\
\text { (\%) }\end{array}$ & $\begin{array}{l}\text { GB } \\
(\mathbf{m m})\end{array}$ \\
\hline 12 & 732 & 1.87 & 1.00 & 51.80 & 83.67 & 0.92 & 3.37 & 87.97 & 4.00 & 2.17 \\
\hline 13 & 445 & 1.81 & 0.95 & 51.95 & 88.00 & 0.95 & 3.35 & 96.50 & 1.00 & 2.20 \\
\hline 14 & 485 & 1.81 & 0.94 & 50.87 & 86.77 & 0.94 & 3.49 & 92.83 & 2.33 & 2.04 \\
\hline 15 & 1426 & 2.07 & 1.05 & 50.08 & 87.00 & 1.03 & 3.53 & 94.27 & 4.00 & 2.68 \\
\hline 16 & 1081 & 2.10 & 1.10 & 51.02 & 89.67 & 1.04 & 3.09 & 96.13 & 2.33 & 1.81 \\
\hline 17 & 1305 & 2.07 & 1.09 & 52.20 & 88.00 & 1.02 & 3.04 & 92.50 & 5.33 & 2.59 \\
\hline 18 & 676 & 1.82 & 0.98 & 53.86 & 86.42 & 0.92 & 3.29 & 70.50 & 0.67 & 2.11 \\
\hline 19 & 590 & 1.88 & 1.01 & 51.92 & 73.93 & 0.92 & 3.50 & 71.73 & 1.23 & 2.23 \\
\hline 20 & 623 & 1.86 & 0.96 & 49.44 & 80.67 & 0.99 & 3.25 & 71.10 & 0.33 & 2.24 \\
\hline 21 & 698 & 2.19 & 1.15 & 51.54 & 90.00 & 1.10 & 3.67 & 69.90 & 7.67 & 2.47 \\
\hline 22 & 819 & 2.07 & 1.11 & 51.93 & 86.00 & 1.01 & 2.86 & 83.00 & 2.00 & 2.03 \\
\hline 23 & 641 & 1.98 & 1.09 & 52.99 & 84.67 & 0.94 & 2.90 & 95.13 & 2.00 & 2.34 \\
\hline 24 & 464 & 1.90 & 1.01 & 50.63 & 79.33 & 1.01 & 4.38 & 91.67 & 1.67 & 2.68 \\
\hline 25 & 583 & 1.88 & 1.02 & 52.93 & 84.67 & 0.90 & 2.78 & 75.23 & 2.00 & 2.55 \\
\hline 26 & 407 & 1.99 & 1.11 & 53.81 & 85.67 & 0.94 & 2.82 & 86.67 & 2.23 & 2.22 \\
\hline 27 & 502 & 1.85 & 1.03 & 53.49 & 83.89 & 0.89 & 2.75 & 71.07 & 10.10 & 2.14 \\
\hline 28 & 532 & 2.01 & 1.08 & 51.84 & 83.43 & 0.95 & 2.43 & 96.90 & 4.43 & 2.55 \\
\hline 29 & 274 & 1.93 & 1.11 & 34.94 & 76.00 & 0.90 & 2.96 & 84.95 & 5.15 & 1.84 \\
\hline 30 & 1156 & 2.18 & 1.17 & 50.46 & 78.67 & 0.98 & 2.61 & 78.80 & 1.00 & 2.77 \\
\hline 31 & 610 & 2.19 & 1.19 & 53.53 & 85.33 & 1.00 & 3.02 & 81.67 & 5.33 & 2.79 \\
\hline 32 & 794 & 2.02 & 1.08 & 50.57 & 85.97 & 0.97 & 2.94 & 84.13 & 0.90 & 2.86 \\
\hline 33 & 692 & 1.94 & 1.03 & 52.10 & 86.67 & 0.95 & 3.08 & 93.00 & 5.33 & 2.23 \\
\hline 34 & 674 & 2.07 & 1.09 & 50.90 & 84.00 & 0.97 & 3.57 & 81.40 & 15.33 & 2.28 \\
\hline 35 & 1118 & 1.97 & 1.03 & 51.60 & 90.33 & 0.99 & 2.98 & 88.93 & 2.00 & 2.43 \\
\hline 36 & 1147 & 2.01 & 1.04 & 50.65 & 90.33 & 0.99 & 3.44 & 86.37 & 2.00 & 2.32 \\
\hline 37 & 769 & 1.96 & 1.03 & 50.86 & 89.00 & 1.02 & 3.16 & 63.47 & 0.67 & 2.05 \\
\hline 38 & 466 & 2.00 & 1.03 & 50.09 & 77.00 & 0.96 & 2.69 & 87.60 & 2.00 & 2.31 \\
\hline 39 & 1129 & 2.10 & 1.08 & 49.52 & 85.67 & 1.08 & 2.76 & 91.43 & 4.33 & 2.31 \\
\hline 40 & 779 & 1.84 & 1.01 & 52.85 & 79.33 & 0.92 & 3.43 & 82.93 & 5.67 & 2.41 \\
\hline 41 & 780 & 187 & 0.95 & 50.59 & 89.17 & 1.03 & 3.04 & 77.40 & 1.33 & 2.06 \\
\hline 42 & 374 & 1.80 & 0.97 & 52.09 & 89.10 & 0.92 & 2.65 & 82.33 & 1.67 & 2.11 \\
\hline 43 & 494 & 1.90 & 1.00 & 52.71 & 88.00 & 0.99 & 3.17 & 89.33 & 2.67 & 2.44 \\
\hline 44 & 295 & 1.67 & 0.93 & 48.98 & 84.08 & 0.93 & 2.15 & 86.40 & 7.33 & 1.84 \\
\hline 45 & 690 & 1.84 & 0.97 & 50.83 & 67.67 & 0.93 & 3.27 & 81.73 & 0.67 & 1.86 \\
\hline 46 & 774 & 1.95 & 1.06 & 53.04 & 90.00 & 0.99 & 3.12 & 81.63 & 4.00 & 2.17 \\
\hline 48 & 1332 & 1.93 & 0.99 & 50.95 & 84.33 & 1.02 & 2.85 & 90.17 & 0.33 & 1.80 \\
\hline 49 & 492 & 2.01 & 1.08 & 51.80 & 88.00 & 0.97 & 3.04 & 77.67 & 4.33 & 2.08 \\
\hline 50 & 1523 & 1.99 & 1.04 & 50.99 & 84.67 & 1.01 & 3.69 & 88.40 & 9.33 & 1.70 \\
\hline 51 & 390 & 1.74 & 0.90 & 45.11 & 73.05 & 1.02 & 2.93 & 94.80 & 5.98 & 1.78 \\
\hline 52 & 633 & 1.91 & 1.08 & 53,90 & 81.67 & 0.89 & 2.93 & 78.33 & 3.00 & 2.01 \\
\hline 53 & 573 & 1.90 & 1.02 & 51.20 & 84.35 & 0.97 & 2.70 & 77.80 & 4.00 & 1.93 \\
\hline
\end{tabular}

*V: Verim, MA:; Meyve ağırlığı, IAA: İç ağılığı, IO: İç oranı, SiO: Sağlam iç oranı, KK: Kabuk kalınlığı, ÇMS: Çotanaktaki meyve sayısı, BO: Beyazlama oranı, ÇMO: Çıtlak meyve oranı, GB: Göbek boşluğu.

\section{Yaprak Analizi Değerleri}

Yaprak analizi sonuçlarına göre; azot \%1.81-2.69, fosfor \%0.85-2.32, potasyum \%0.06-16.87, demir 196.1671.7 ppm, bakır 5.2-198 ppm, mangan 63.9-1444 ppm, bor 11.14-58.52 ppm ve çinko 41.29-62.45 ppm arasında belirlenmiştir (Çizelge 3). Yaprak analizi sonuçlarının Çizelge 4'deki skalaya göre değerlendirilmesi sonucunda; araştırma kapsamında analizi yapılan 53 örneğin \%62.3'de azot, \%98.1'de bor, \%35.8'de mangan ve \%1.9'da potasyum eksikliği belirlenmiştir. Fosfor, kalsiyum, magnezyum, demir ve çinko eksikliğine rastlanmamıştır. Fındığın gelişmesi için ihtiyacı olan besin maddeleri sadece azot, fosfor ve potasyum olmayıp genel fonksiyonları ve yaptıkları işlem bakımından bunlar kadar önemli olan $\mathrm{Ca}, \mathrm{Mg}, \mathrm{Fe}, \mathrm{Mn}, \mathrm{Zn}, \mathrm{Cu}, \mathrm{B}$ gibi besin maddelerini de kapsadığı ve bu besin maddelerinin noksanlığının fındıkta yapraklarda sararma ve deformasyonlar, meyve dökümleri ve boş fındık oluşumunun artması şeklinde yer yer görülmeye başlandığı ifade edilmiştir. Bu nedenle yaprak analizlerine göre noksanlığı saptanan elementlerin uygulanmasının fındığın gelişmesi ve verimi üzerine olumlu etki yapacağı vurgulanmıştır (Anonim, 2021c). 
Bor noksanlığı genel olarak ılıman iklime sahip ve bol yağış olan bölgelerde görülmektedir. Ordu yöresinde yıllık yağış miktarının yüksek olmasıyla ilişkili olarak en fazla noksanlığı görülen mikro elementlerden Zn ve B'un ön plana çıktığı ifade edilmiştir. Son yıllarda dünya genelinde mikro besin elementleriyle ilgili olarak bitkisel üretimde en yaygın beslenme sorununun özellikle B ve $Z n$ elementlerinden kaynaklandığı ileri sürülmektedir. Bitkilerin beslenmesinde $\mathrm{Zn}$ ve $\mathrm{B}$ arasında birbirinin alınımını teşvik eden etkileşim bulunmaktadır (Özkutlu ve ark., 2019).

Çizelge 3. Yaprakların besin elementi içerikleri. Table 3. Nutrient content of leaves.

\begin{tabular}{|c|c|c|c|c|c|c|c|c|}
\hline No & $\begin{array}{l}\mathbf{N} \\
(\%)\end{array}$ & $\begin{array}{l}\mathbf{P} \\
(\%)\end{array}$ & $\begin{array}{l} \\
(\%)\end{array}$ & $\begin{array}{l}\text { Fe } \\
\text { (ppm) }\end{array}$ & $\begin{array}{l}\text { Cu } \\
\text { (ppm) }\end{array}$ & $\begin{array}{l}\text { Mn } \\
\text { (ppm) }\end{array}$ & $\begin{array}{l}\text { B } \\
\text { (ppm) }\end{array}$ & $\begin{array}{l}\mathrm{Zn} \\
\text { (ppm) }\end{array}$ \\
\hline 1 & 2.06 & 1.49 & 14.03 & 485.20 & 9.40 & 677.10 & 18.21 & 55.16 \\
\hline 2 & 2.26 & 1.14 & 13.98 & 268.40 & 8.45 & 262.60 & 21.32 & 52.05 \\
\hline 3 & 2.32 & 0.86 & 0.06 & 217.10 & 5.20 & 578.90 & 11.14 & 41.29 \\
\hline 4 & 2.03 & 1.14 & 11.45 & 507.00 & 10.90 & 1444 & 18.33 & 57.45 \\
\hline 5 & 2.39 & 1.36 & 10.94 & 376.60 & 9.30 & 290.30 & 58.52 & 53.45 \\
\hline 6 & 2.38 & 1.26 & 13.87 & 403.40 & 10.39 & 457.80 & 39.75 & 59.18 \\
\hline 7 & 2.22 & 1.63 & 16.87 & 533.10 & 12.55 & 804.50 & 27.67 & 56.59 \\
\hline 8 & 2.20 & 1.29 & 9.66 & 385.40 & 9.58 & 829.70 & 15.77 & 51.38 \\
\hline 9 & 2.44 & 1.51 & 10.78 & 404.30 & 8.51 & 228.50 & 22.34 & 51.36 \\
\hline 10 & 2.15 & 1.74 & 11.77 & 374.30 & 8.20 & 391.80 & 24.22 & 59.30 \\
\hline 11 & 2.32 & 1.06 & 6.30 & 405.80 & 6.90 & 557.70 & 12.95 & 47.19 \\
\hline 12 & 2.10 & 1.80 & 14.39 & 473.00 & 12.07 & 407.30 & 35.05 & 62.45 \\
\hline 13 & 2.38 & 1.53 & 11.63 & 557.90 & 11.65 & 730.60 & 21.19 & 53.80 \\
\hline 14 & 2.26 & 1.15 & 6.90 & 308.90 & 7.69 & 622.70 & 16.63 & 44.24 \\
\hline 15 & 2.15 & 1.58 & 15.52 & 548.50 & 11.36 & 531.30 & 24.71 & 59.64 \\
\hline 16 & 2.20 & 1.05 & 12.54 & 322.40 & 18.20 & 194.50 & 38.31 & 47.05 \\
\hline 17 & 2.28 & 1.03 & 10.30 & 492.30 & 14.45 & 513.80 & 35.71 & 48.45 \\
\hline 18 & 2.32 & 1.27 & 9.66 & 532.40 & 14.27 & 1366 & 16.52 & 50.14 \\
\hline 19 & 2.29 & 1.25 & 6.87 & 292.80 & 10.62 & 457.10 & 34.55 & 49.07 \\
\hline 20 & 2.17 & 1.30 & 8.60 & 348.30 & 10.33 & 92.93 & 24.71 & 46.38 \\
\hline 21 & 2.22 & 1.35 & 8.72 & 310.00 & 10.71 & 429.50 & 21.03 & 49.59 \\
\hline 22 & 2.16 & 1.37 & 9.82 & 364.75 & 197.98 & 413.32 & 23.74 & 51.71 \\
\hline 23 & 2.02 & 1.17 & 12.38 & 367.20 & 11.49 & 178.00 & 23.07 & 48.97 \\
\hline 24 & 2.05 & 1.44 & 6.49 & 346.50 & 10.62 & 112.60 & 31.84 & 49.55 \\
\hline 25 & 1.87 & 1.46 & 10.64 & 522.10 & 20.50 & 151.50 & 17.74 & 51.19 \\
\hline 26 & 2.10 & 1.45 & 9.35 & 424.50 & 9.84 & 84.13 & 21.38 & 52.69 \\
\hline 27 & 2.48 & 1.52 & 9.03 & 515.70 & 15.48 & 178.30 & 21.95 & 53.59 \\
\hline 28 & 2.04 & 1.55 & 9.57 & 505.90 & 11.01 & 130.40 & 15.56 & 53.89 \\
\hline 29 & 2.14 & 2.32 & 7.25 & 671.70 & 10.76 & 208.70 & 17.69 & 60.79 \\
\hline 30 & 2.40 & 2.00 & 11.09 & 504.80 & 11.13 & 119.60 & 28.46 & 50.98 \\
\hline 31 & 2.18 & 1.33 & 8.93 & 282.80 & 10.11 & 125.30 & 25.44 & 46.46 \\
\hline 32 & 1.99 & 1.49 & 13.22 & 475.20 & 9.02 & 289.80 & 25.29 & 59.12 \\
\hline 33 & 2.21 & 0.93 & 5.87 & 247.00 & 10.84 & 246.00 & 23.10 & 45.32 \\
\hline 34 & 2.19 & 1.23 & 8.24 & 375.90 & 13.44 & 145.20 & 38.62 & 55.30 \\
\hline 35 & 2.26 & 1.66 & 13.49 & 327.70 & 10.46 & 638.20 & 18.23 & 55.20 \\
\hline 36 & 2.69 & 1.46 & 10.16 & 314.80 & 9.47 & 1300 & 21.94 & 56.83 \\
\hline 37 & 2.06 & 1.28 & 14.52 & 329.60 & 7.95 & 383.30 & 22.09 & 51.65 \\
\hline 38 & 2.31 & 1.46 & 7.62 & 300.70 & 12.28 & 85.66 & 15.95 & 53.38 \\
\hline 39 & 1.92 & 1.58 & 16.14 & 289.90 & 8.87 & 537.40 & 43.10 & 59.46 \\
\hline 40 & 1.81 & 1.20 & 11.56 & 219.40 & 7.72 & 790.90 & 12.99 & 55.66 \\
\hline 41 & 1.91 & 1.40 & 9.65 & 206.40 & 9.64 & 271.10 & 17.33 & 50.64 \\
\hline 42 & 2.08 & 1.00 & 10.77 & 233.90 & 15.03 & 396.90 & 17.95 & 51.14 \\
\hline 43 & 1.91 & 1.65 & 5.52 & 313.80 & 8.53 & 609.20 & 23.67 & 48.96 \\
\hline 44 & 1.96 & 1.12 & 3.06 & 268.80 & 8.39 & 312.80 & 15.52 & 51.72 \\
\hline 45 & 1.86 & 1.16 & 6.06 & 214.20 & 6.89 & 190.70 & 22.95 & 46.02 \\
\hline 46 & 1.83 & 1.21 & 5.59 & 321.40 & 7.31 & 63.90 & 18.28 & 44.36 \\
\hline 47 & 2.17 & 1.27 & 4.72 & 233.60 & 8.44 & 189.60 & 18.95 & 46.53 \\
\hline 48 & 2.43 & 1.62 & 7.21 & 305.80 & 7.99 & 109.60 & 26.42 & 43.39 \\
\hline 49 & 2.28 & 1.37 & 9.69 & 196.10 & 9.04 & 107.60 & 22.72 & 49.85 \\
\hline 50 & 2.15 & 1.50 & 7.81 & 211.90 & 7.95 & 247.00 & 28.75 & 54.42 \\
\hline 51 & 1.84 & 0.85 & 9.45 & 273.50 & 6.67 & 854.00 & 23.09 & 44.58 \\
\hline 52 & 1.93 & 1.35 & 11.06 & 254.50 & 9.04 & 153.30 & 12.10 & 50.49 \\
\hline 53 & 2.25 & 1.59 & 8.47 & 433.90 & 8.51 & 253.50 & 34.83 & 51.87 \\
\hline
\end{tabular}


Çizelge 4. Tombul çeşidinin bitki besin elementi sınır değerleri.

Table 4. Plant nutrition limit values in Tombul hazelnut cultivar.

\begin{tabular}{|c|c|c|c|c|}
\hline Bitki Besin Elementi & Çok Az & $\mathbf{A z}$ & Yeterli & Fazla \\
\hline$\% \mathrm{~N}$ & $<1.89$ & $1.90-2.25$ & $2.26-2.55$ & $>2.56$ \\
\hline \%P & $<0.07$ & $0.08-0.13$ & $0.14-0.35$ & $>0.36$ \\
\hline \%K & $<0.39$ & $0.40-0.84$ & $0.85-2.00$ & $>2.01$ \\
\hline$\% \mathrm{Ca}$ & $<0.79$ & $0.80-1.20$ & $1.21-1.65$ & $>1.66$ \\
\hline$\% \mathrm{Mg}$ & $<0.14$ & $0.15-0.24$ & $0.25-0.40$ & $>0.41$ \\
\hline $\mathrm{Fe}(\mathrm{ppm})$ & $<40$ & $41-80$ & $81-325$ & $>326$ \\
\hline Cu (ppm) & $<2.0$ & $2.1-6.0$ & $6.1-20.0$ & $>20.1$ \\
\hline Mn (ppm) & $<80.0$ & $80.1-250.0$ & $250.1-750.0$ & $>750.1$ \\
\hline B (ppm) & $<14.0$ & $14.1-45.0$ & $45.1-85.0$ & $>85.1$ \\
\hline Zn (ppm) & $<14.0$ & $14.1-25.0$ & $25.1-60.0$ & $>60.1$ \\
\hline
\end{tabular}

*(Duyar ve Özenç, 2013).

\section{incelenen Parametreler Arasındaki Korelasyon Katsayıları}

Korelasyon analizi sonucunda, incelenen parametrelerin birçoğu arasındaki karşılıklı ilişkinin önemli çıktığı görülmektedir. Verim ile meyve ağırlığı $\left(r=0.390^{* *}\right)$, kabuk kalınlığı $\left(r=0.382^{* *}\right)$ ve yapraklardaki B elementi içeriği $\left(r=0.429^{* *}\right)$ arasında ilişkinin önemli olduğu belirlenmiştir. Meyve ağırlığı ile iç ağırlığı $\left(r=0.889^{* *}\right)$, sağlam iç oranı $\left(r=0.303^{*}\right)$, kabuk kalınlığı $\left(r=0.564^{* \star}\right)$ ve göbek boşluğu $\left(r=0.473^{* *}\right)$ arasında ilişkilerin önemli olduğu saptanmıştır. iç ağırlığı ile göbek boşluğu $\left(r=0.405^{* *}\right)$ ve $\mathrm{Mn}$ içeriği $\left(r=-0.349^{*}\right)$; iç oranı ile sağlam iç oranı $\left(r=0.432^{* *}\right)$; sağlam iç oranı ile kabuk kalınlığı $\left(r=0.319^{*}\right)$; göbek boşluğu ile $K$ içeriği $\left(r=0.342^{*}\right)$; K içeriği ile $B$ içeriği $\left(r=0.300^{*}\right)$ arasında ilişkilerin önemli olduğu tespit edilmiştir (Çizelge 5). Iş̧bakan ve Bostan (2020), verim ile dal boyu $\left(r=0.609^{* *}\right)$, gövde çevresi $\left(r=0.769^{* *}\right)$, toplam çotanak sayısı $\left(r=0.639^{* *}\right)$, toplam meyve sayısı $\left(r=0.928^{* *}\right)$, boş meyve oranı $\left(r=-0.764^{\star *}\right)$, meyve hacmi $\left(r=0.522^{\star}\right)$, meyve yoğunluğu $\left(r=-0.582^{*}\right)$, iç şekil indeksi $\left(r=0.574^{\star}\right)$, iç hacmi $\left(r=0.491^{*}\right)$ ve iç yoğunluğu $\left(r=-0.597^{\star *}\right)$ arasındaki ilişkinin önemli olduğunu belirtmişlerdir (Çizelge 5). Akçin ve Bostan (2019), fındıkta toplam döllenmiş karanfil sayısı, toplam çotanak sayısı, hasattaki toplam çotanak sayısı ve toplam dal sayısı ile ortalama verim arasında pozitif bir ilişkinin olduğunu bildirmiştir.

Çizelge 5. Incelenen özellikler arasındaki ilişkilere ait korelasyon katsayıları.

Table 5. Correlation coefficients for the relationships between the investigated characteristics.

\begin{tabular}{|c|c|c|c|c|c|c|c|c|c|c|c|c|c|}
\hline & $\mathbf{v}$ & MA & İA & io & sio & KK & ÇMS & BO & ÇMO & GB & $\mathbf{N}$ & $\mathbf{K}$ & Mn \\
\hline MA & $3.390^{* *}$ & & & & & & & & & & & & \\
\hline İ & 0.206 & $0.889^{* *}$ & & & & & & & & & & & \\
\hline io & 0.137 & 0.056 & 0.071 & & & & & & & & & & \\
\hline sio & 0.224 & $0.303^{*}$ & 0.251 & $0.432^{* *}$ & & & & & & & & & \\
\hline KK & $3.382^{* *}$ & $0.564^{* *}$ & 0.230 & -0.117 & $0.319^{*}$ & & & & & & & & \\
\hline ÇMS & 0.178 & 0.122 & 0.001 & 0.073 & 0.018 & 0.237 & & & & & & & \\
\hline BO & 0.097 & 0.035 & -0.033 & -0.055 & 0.009 & 0.033 & -0.026 & & & & & & \\
\hline ÇMO & 0.026 & 0.070 & 0.177 & -0.041 & 0.028 & -0.047 & 0.105 & -0.038 & & & & & \\
\hline GB & 0.008 & $0.473^{* *}$ & $0.405^{* *}$ & 0.201 & 0.119 & 0.159 & 0.051 & 0.038 & -0.116 & & & & \\
\hline$N$ & J.240 & 0.254 & 0.209 & 0.101 & 0.250 & -0.005 & 0.117 & 0.028 & -0.006 & -0.051 & & & \\
\hline K & 0.228 & 0.264 & 0.179 & 0.080 & 0.139 & 0.089 & -0.046 & 0.210 & -0.194 & $0.342^{*}$ & -0.015 & & \\
\hline $\mathrm{Mn}$ & 0.074 & -0.258 & $-0.349^{*}$ & 0.014 & -0.008 & -0.067 & 0.163 & 0.169 & -0.096 & -0.046 & 0.128 & 0.208 & \\
\hline B & $3.429^{* *}$ & 0.230 & 0.138 & -0.009 & 0.016 & 0.240 & 0.156 & 0.141 & 0.102 & -0.018 & 0.207 & $0.300^{*}$ & -0.170 \\
\hline
\end{tabular}

* $\mathrm{P}<0.01$, * $\mathrm{P}<0.05$. V: Verim, MA:, Meyve ağırlığı, IA: Iç̧ ağırlığı, İO: İç oranı, SiO: Sağlam iç oranı, KK: Kabuk kalınlığı, ÇMS: Çotanaktaki meyve sayısı, BO: Beyazlama oranı, ÇMO: Çıtlak meyve oranı, GB: Göbek boşluğu.

\section{Regresyon ve Kümeleme Analizleri}

İncelenen özelliklerde Stepwise Regresyon analiz yöntemine göre verim üzerine B elementi içeriği ile birlikte, meyve ağırlığının pozitif yönde etkisi söz konusu iken, iç ağırlığının negatif yönde etkisi belirlenmiştir (Çizelge 6). Verime etki eden özellikler dikkate alınarak oluşturulan kümeleme Ward yöntemi analizi sonucunda bitkilerin 3 gruba ayrıldığı tespit edilmiştir (Şekil 1). 


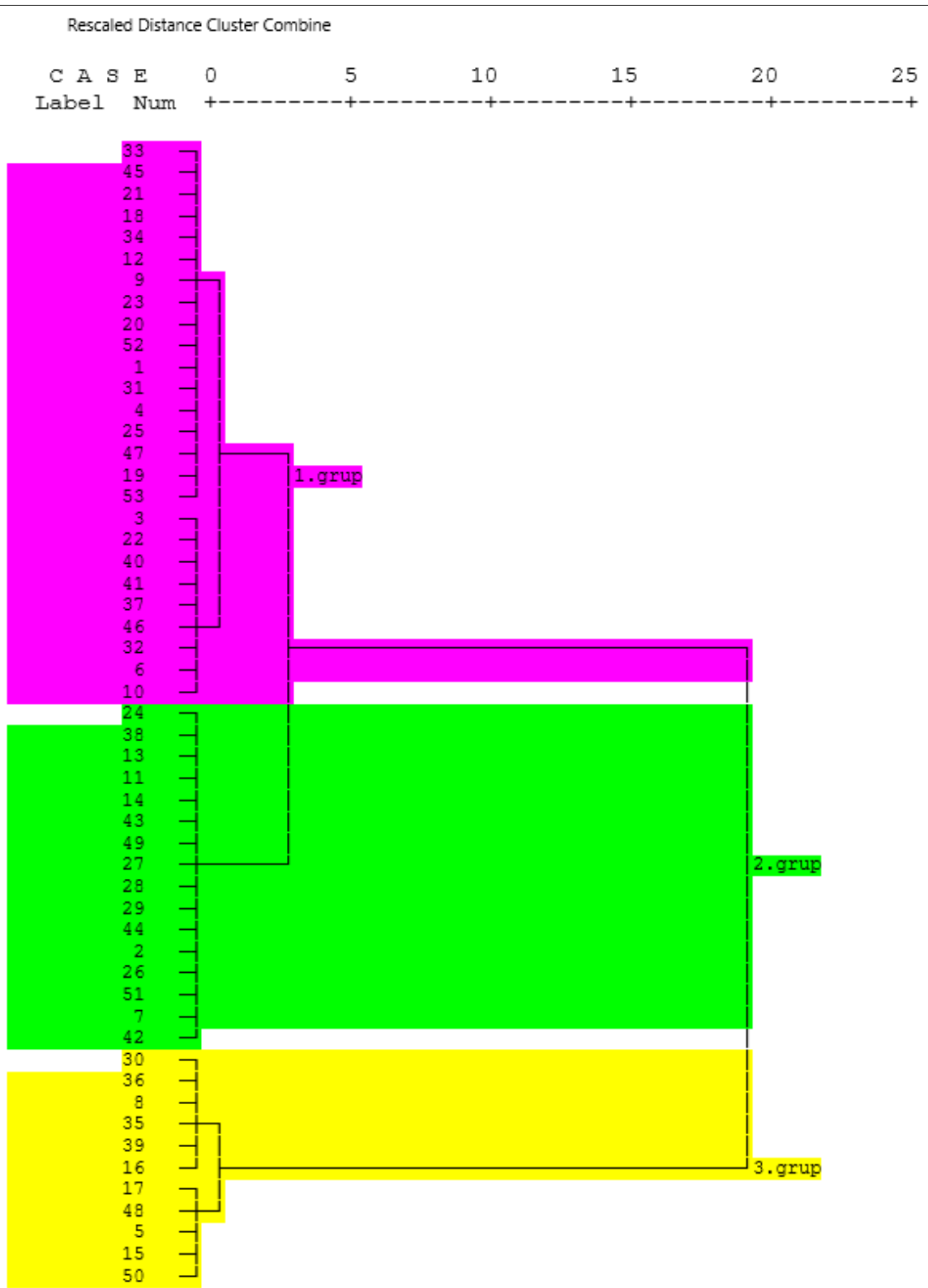

Şekil 1. Cluster Ward Analizine göre bitkilerin gruplandırılması.

Figure 1. Grouping of plants according to Cluster Ward Analysis.

1. grupta ve 2. grupta verim, sağlam iç oranı, beyazlama oranı düşük olan bitkiler yer alırken bu gruplarda yer alan bitkilerin yapraklarında besin elementi içeriklerinin ortalamanın oldukça altında olduğu dikkati çekmektedir. 3. gruptaki bitkilerde verimin oldukça yüksek olduğu, meyve kalite özelliklerinin 1.ve 2 gruptaki bitkilere nazaran daha iyi ve besin elementlerinden özellikle bor bakımından oldukça zengin olduğu tespit edilmiştir. Fındıkta bor uygulamalarının meyve tutumunu artırdığı ve boş meyve oranının azalttığı bilinmektedir. Okay ve ark. (1986), yapraktan \% $1^{\prime}$ lik $\mathrm{H}_{3} \mathrm{BO}_{3}$ 'ten $3.5 \mathrm{~L} \mathrm{ocak}^{-1}$ ve topraktan $125 \mathrm{~g} \mathrm{ocak}^{-1}$ boraks uygulamalarının boş fındık oluşumunu azalttığını belirlemiştir. Aynı zamanda Cacka and Smith (2009), mayıs ve haziran ortasında yapraktan yapılan bor uygulaması ile verimde \%28-40 düzeyinde artış sağlanabileceğini vurgulamıştır.

Halbuki Giresun ilindeki fındık bahçelerinin \%94.3'nün, Trabzon ilindeki fındık bahçelerinin ise \%91.3'nün bor elementi içeriği bakımından 'çok az' (0.5ppm'in altı) ve 'az' (0.5-0.99ppm arası) aralığında olduğunu belirtilmiştir (Anonim, 2015). 
Çizelge 6. Back Ward Yöntemine göre regresyon analizi.

Table 6. Regression analysis according to the Back Ward Method.

\begin{tabular}{|c|c|c|c|c|c|}
\hline \multirow[b]{2}{*}{ Model } & \multicolumn{2}{|c|}{ Standartlandırılmamış Katsayılar } & \multirow{2}{*}{$\begin{array}{l}\text { Standartlaştırılmış Katsayılar } \\
\text { Beta }\end{array}$} & \multirow[b]{2}{*}{$\mathbf{t}$} & \multirow[b]{2}{*}{ Sig. } \\
\hline & B & Std. Error & & & \\
\hline 1 (Constant) & 373.699 & 112.884 & & 3.310 & .002 \\
\hline B & 14.992 & 4.422 & .429 & 3.391 & .001 \\
\hline 2 (Constant) & -1217.547 & 650.683 & & -1.871 & .067 \\
\hline B & 12.520 & 4.330 & .358 & 2.891 & .006 \\
\hline Meyve Ağırlığı & 844.595 & 340.614 & .307 & 2.480 & .017 \\
\hline 3 (Constant) & -934.706 & 639.492 & & -1.462 & .150 \\
\hline B & 11.122 & 4.218 & .318 & 2.637 & .011 \\
\hline Meyve Ağırlığı & 2260.735 & 718.226 & .822 & 3.148 & .003 \\
\hline İç Ağırlığı & -2895.968 & 1306.625 & -.569 & -2.216 & .031 \\
\hline
\end{tabular}

a. bağımlı değişken: verim.

Stepwise yönteminin Standartlaştırılmış Katsayılarına göre regresyon denklemi:

$$
\begin{aligned}
& X_{1}=B \quad X_{2}=\text { Meyve Ağırlığı } \quad X_{3}=I_{c ̧} \text { Ağırlığı } \\
& Y i=0.318 x_{1}+0.822 x_{2}-0.569 x_{3}
\end{aligned}
$$

Stepwise yönteminin Standartlandırılmamış Katsayılarına göre regresyon denklemi:

$$
Y i^{\prime}=-934.71+11.12 x_{1}+2260.73 x_{2}-2895.97 x_{3}
$$

\section{SONUÇ}

Giresun ve Trabzon illerindeki Tombul fındık bahçelerinde önemli düzeyde azot, bor, mangan eksikliğinin bulunduğu ve az miktarda da potasyum eksikliği bulunduğu belirlenmiştir. Korelasyon ve regresyon analizine göre verim ile bor seviyesi arasındaki ilişki önemli bulunurken, meyve kalitesi ile incelenen besin elementleri arasında pozitif bir ilişkinin olduğu ortaya çıkarılmıştır. Sonuç olarak, fındık bahçelerinde uygun doz, uygulama şekli ve zamanı yönünden uygulanacak gübreleme programının toprak ve yaprak analizi ışığında belirlenmesinin bir zorunluluk olduğu ifade edilebilir.

\section{ÇIKAR ÇATIŞMASI}

Yazarlar arasında herhangi bir çıkar çatışması bulunmamaktadır.

\section{YAZAR KATKISI}

Hüseyin İfan Balık çalışmanın planlanması, yürütülmesi ve makalenin yazımında katkı sağlarken, arazi çalışmaları Selda Kayalak Balık, laboratuvar çalışmaları ise Ömür Duyar tarafından yapılmıştır.

\section{TEŞEKKÜR}

İstatistiksel analizleri gerçekleştiren Dr. Öğr. Üyesi Ferzat Turan'a teşekkür ederiz. Bu araştırma Tarımsal Araştırmalar ve Politikalar Genel Müdürlüğü (TAGEM) tarafından desteklenmiştir.

\section{KAYNAKLAR}

Akçin, Y., \& Bostan, S. Z. (2019). Farklı sulama programlarının 'tombul' fındık çeşidinde depolama süresince su aktivitesine etkisi. Uluslararası Tarım ve Yaban Hayatı Bilimleri Dergisi, 5(2), 308-313.

Anonim. (2015). Bor gübrelemesinin Orta karadeniz havzası bölgesinde yetiştirilen fındık bitkisinin verim ve verim unsurları üzerine etkisi. Proje Sonuç Raporu, BOREN, Proje No: 2012.ç0368, Ankara.

Anonim. (2021a). Karadeniz ihracatçı birlikleri genel sekreterliği istatistikleri. http://www.kib.org.tr/files/downloads/20182019.pdf. Erişim tarihi: 27 Şubat 2021. 
Anonim. $\quad$ (2021b). $\quad$ Fındık $\quad$ araştırma $\quad$ enstitüsü, çiftçi $\quad$ eğitim serisi https://arastirma.tarimorman.gov.tr/findik/Belgeler/Sol\%20Men\%C3\%BC/E\%C4\%9Fitim\%20ve\%20Yay\%C4\%B1m/\%C3\% 87ift\%C3\%A7i\%20E\%C4\%9Fitim/YaprakveToprakOrnegiAlinmasi.pdf. Erişim tarihi: 02 Mart 2021.

Anonim. (2021c). Fındık araştırma enstitüsü bilgi bankası https://arastirma.tarimorman.gov.tr/findik/Sayfalar/Detay.aspx?Sayfald=22. Erişim tarihi: 27 Şubat 2021.

Balık, H. İ., Kayalak Balık, S., Beyhan, N., \& Erdoğan, V. (2016). Fındık Çeşitleri (Hazelnut Cultivars). Klasmat Matbaacılık, 96s, Trabzon, Türkiye.

Balık, H. I., \& Beyhan, N. (2019). Pollen compatibility in Turkish hazelnut cultivars. Turkish Journal of Food and Agriculture Sciences, 1(1), 12-17.

Beyhan, N., Demir, T., \& Sürücü, A. (1998). Farklı azot dozlarının palaz fındık çeşidinde verim, meyve kalitesi ve beslenme Üzerine Etkisi. Ondokuzmayıs Üniversitesi Ziraat Fakültesi Dergisi, 13(1), 1-13.

Borges, O. M. P., Carvalho, J. L. R. S., Silva, A. P., \& Santos, A. 2001. Effects of foliar boron sprays on yield and nut quality of 'Segorbe' and 'Fertile de Coutard' hazelnuts. Proceedings V. International Congress on Hazelnut, Acta Horticulturae, 556, 300-302.

Bostan, S. Z. (2019). Fındıkta kabuklu ve iç meyve kusurları. Akademik Ziraat Dergisi, 8, 157-166.

Cacka, J. F., \& Smith, F. (2009). Foliar nutrition applied at early hazelnut development shows positive yield and quality factors in the will. valley of oregon. Acta Horticulture, 845, 343-348.

Coşkun, N. (2010). Fındık bahçelerinde toprak ve ürünlerdeki mikro element dağıımının ve aralarındaki korelasyonun incelenmesi. Doktora Tezi, İstanbul Teknik Üniversitesi, Fen Bilimleri Enstitüsü, İstanbul.

Duyar, Ö., \& Özenç, N. (2013). Fındıkta Bitki Besleme ve Gübreleme Teknikleri. Fındık Araştırma Enstitüsü, Giresun.

Erdoğan, V., \& Mehlenbacher, S. A. (2000). Interspecific hybridization in hazelnut (Corylus). Journal of American Society for Horticultural Sciences, 125, 489-497.

FAO. (2021). Bitkisel üretim istatistikleri. http://www.fao.org/faostat/en/\#data/QC. Erişim tarihi: 27 Şubat 2021.

Germain, E. (1990). Hazelnut production and industry in Europe, north Africa and middle east. Nut production and industry in Europe, near east and North Africa, Yalova, Turkey.

Germain, E. (1994). The reproduction of hazelnut (Corylus avellana L.): A review. Acta Horticulturae, 351, 195-209.

Herrera, E. A. (2001). Fertilization programs for apple orchards. Guide H-319. Extension horticulturist college of agriculture and home economics. New Mexico State University.

Horuz, A., \& Korkmaz, A. (2011). Samsun Terme yöresinde yetiştirilen palaz fındık çeşidinin yaprak besin element oranlarını değerlendirerek dengesiz gübrelemeden kaynaklanan beslenme sorunlarının tespiti. Samsun Sempozyumu, Samsun.

İşbakan, H., \& Bostan, S. Z. (2020). Fındıkta bitki morfolojik özellikleri ile verim ve meyve kalite özellikleri arasındaki ilişkiler. Ordu Üniversitesi Bilim ve Teknoloji Dergisi, 10(1), 32-45

Kacar, B., \& İnal, A. (2008). Bitki Analizleri. Nobel Yayın Dağıtım, Ankara.

Keeney, D. R. (1982). Nitrogen: availability indices. In A. L. Page (Ed). Methods of Soil Analysis 2 (pp. 711-733). Madison, USA: Agronomy Monographs.

Nicolosi, E., Leotta, G., \& Raiti, G. (2009). Effect of foliar fertilization on hazelnuts growing in mount etna area. VII International Congress on Hazelnut. Acta Horticulture, 845, 373-378.

Okay, A. N., Kaya, A., Küçük, V. Y., \& Küçük, A. (1986). Fındık Tarımı. Tarım-Orman ve Köyişleri Bakanlığı, Yayın No: 142, Ankara.

Okay, A. N., Koç, N., \& Kılavuz, F. H. (1987). Boş fındık oluşum sebepleri ve giderilmesi üzerine araştırmalar. Sonuç Raporu. T.C. Tarım, Orman ve Köy işleri Bakanlığı, Proje ve Uygulama Genel Müdürlüğü, Fındık Araştırma ve Eğitim Merkezi Müdürlüğü, Giresun.

Özenç,N., Özenç, D.B., \& Duyar, Ö. (2014). Nutritional composition of hazelnut (Corylus avellana L.) as influenced by basic fertilization, Acta Agriculturae Scandinavica, Section B - Soil \& Plant Science, 64, 8.

Özkutlu F., Korkmaz, K., Akgün, M., \& Ete, Ö. (2016). Magnezyum gübrelemesinin fındığın (Corylus avellana L.) verim ve bitki besin elementi içeriklerine etkisi. Ordu Üniversitesi Bilim ve Teknoloji Dergisi, 6, 48-58.

Özkutlu F., Aydemir, Ö. E., Akgün, M., \& Özcan, B. (2019). Ordu ilinde fındık (Corylus avellana L.) tarımı yapılan toprakların çinko $(\mathrm{Zn})$ beslenme durumu ve potansiyel beslenme problemlerinin belirlenmesi. Akademik Ziraat Dergisi, 8(Özel Sayı), 131-140. 
Pannico, A. (2014). Improving hazelnut quality at harvest and non-destructive assessment of post-harvest nut quality. Doctoral Dissertation, Universita Degli Studi Di Napoli Federico II, Dipartimonte Di Argaria, Maggio.

Roversi, A., \& Ughini, V. (2004). Further investigations into the mineral uptake of hazelnut orchards. International VI. International Congress on Hazelnut, Acta Horticulturae, 686, 285-290. 